\title{
RELATIONSHIP BETWEEN KNOWLEDGE AND ATTITUDE WITH SEX BEHAVIOR OF TEENANGER AT SMKN 1 BENGKULU
}

\author{
Hanifah $^{1}$, Ade Herman Surya Direja ${ }^{2}$, Jesshinta Ramayani ${ }^{3}$ \\ ${ }^{123}$ Program Studi Ilmu Keperawatan STIKES Tri Mandiri Sakti Bengkulu \\ E-mail: ns hanifah@yahoo.com
}

\section{Abstract}

Free sex behavior is a sexual activity that carried out without being based on a legal marriage relationship. Among adolescents the behavior occurs because most of them do not know the impact of free sex behavior. In addition, free sex behavior can also damage their future. This study aimed to determine the relationship between knowledge, attitudes, and sexual behavior among adolescent in SMKN 1 Bengkulu City. A quantitative study with cross sectional design was conducted in 80 respondents, who were selected using simple random sampling. Most of the respondents had good level of knowledge (78.8\%), had most favorable attitudes $(81.2 \%)$ and had most low risk sexual behavior (90.0\%). The data were analyzed by using Fisher's Exact test, and obtained p-value $=0.001$. It is showed that, there is relationship between knowledge and sexual behavior, with moderate category. There is relationship between attitude and sex behavior with $p$-value $=0,000$ with a close category. It is recommended that SMKN 1 through counseling teachers to provide health education about sexual behavior and its effects so as to prevent free sex behavior among adolescents.

Keywords: knowledge, sex behavior of teenanger, attitude.

\section{PENDAHULUAN}

Masa remaja merupakan masa transisi mulai dari masa anak-anak ke masa dewasa, selama masa remaja akan terjadi penambahan kecepatan pertumbuhan, dimulai dari tanda - tanda seks sekunder pada laki-laki maupun pada perempuan dan mulai terjadi fertilitas dan terjadi berbagai perubahan psikososial. Pada masa ini remaja mempunyai keingintahuan yang sangat tinggi mengenai seks (Soetjiningsih, 2004).

Menurut Sarwono (2012) secara psikologis bentuk perilaku seks remaja pada dasarnya adalah normal, sebab prosesnya memang dimulai dari rasa tertarik kepada orang lain, muncul gairah diikuti puncak kepuasan dan diakhiri dengan penenangan. Ukuran normal ini akan menjadi berbeda ketika norma masyarakat dan norma agama terlibat. Di Indonesia sendiri norma masyarakat dan norma 
agama tidak mengizinkan adanya perilaku seks bebas/seks pranikah. Di Indonesia, hasil Survei Kesehatan Reproduksi Remaja Indonesia (SKRRI) 2012 mendapatkan $29,5 \%$ remaja laki-laki dan $6,2 \%$ remaja perempuan pernah meraba atau merangsang pasangannya, 48,1\% remaja laki-laki dan 29,3\% remaja perempuan pernah berciuman bibir, serta 79,6\% remaja laki-laki dan 71,6\% remaja perempuan pernah berpegangan tangan dengan pasangannya. Hasil survey 2010 yang dilakukan BKKBN; tercatat 51\% remaja Jabodetabek sudah tidak perawan lagi, di Surabaya tercatat 54\%, di Bandung 47\% dan 52\% di Medan dan Yogyakarta 37\% dan estimasi jumlah aborsi di Indonesia per tahun mencapai 2,4 juta jiwa dan 800 ribu diantaranya terjadi dikalangan remaja. Tingginya jumlah aborsi saat ini, erat kaitannya dengan hubungan seks pranikah dikalangan remaja dikarenakan kurangnya pengetahuan remaja akan reproduksi sehat.

Kurangnya pengetahuan seks remaja menyebabkan meningkatnya perilaku seks bebas dikalangan remaja sehingga meningkatkan resiko kehamilan usia remaja dan penyakit menular seksual (Soetjiningsih, 2004). Kurangnya pengetahuan remaja dikarenakan remaja kurang menerima dan menghargai arahan yang diberikan dari orangtua, sehingga remaja lebih senang menggali informasi mengenai seks bebas dengan teman-teman terdekatnya. Pengetahuan merupakan salah satu faktor yang mempengaruhi terbentuknya sikap, beberapa sikap yang salah pada remaja seperti sikap agresif terhadap lawan jenis, sikap yang tidak berlandaskan moral, dan sikap mentabukan seks pada remaja (Dianawati, 2006).

Sikap mentabukan seks ini tidak hanya terdapat pada orang tua saja, tetapi juga pada anak-anak itu sendiri. Sikap mentabukan seks pada remaja hanya mengurangi kemungkinan untuk membicarakannya secara terbuka, tetapi tidak menghambat hubungan seks itu sendiri (Sarwono, 2006). Menurut Sofyan (2012), pada remaja sekitar 16\% remaja mengaku sudah berpengalaman melakukan hubungan seks pada usia 13-15 tahun, dan 44\% diusia 16-18 tahun.

Kepala Perwakilan BKKBN Bengkulu Widati mengatakan, dari hasil survei RPJM tahun 2011 menunjukan ada 3,1 \% remaja Bengkulu melakukan hubungan seks 
sebelum menikah dengan pacarnya, 5,1\% dilakukan remaja laki-laki dan dan satu persennya dilakukan remaja wanita. hasil survei tersebut juga didapatkan bahwa 2,3\% remaja di Bengkulu telah melakukan hubungan seks sebelum menikah yang bukan dengan pacarnya ( Berita Satu, 2013).

Menurut Haris dalam Githa (2013), dari sisi kesehatan perilaku seks bebas bisa menimbulkan berbagai ganguan, diantaranya terjadi kehamilan yang tidak diinginkan, dan tentunya cenderung untuk aborsi, juga menjadi salah satu penyebab munculnya anak-anak yang tidak diinginkan. Fakta menunjukkan bahwa sebagian besar remaja tidak mengetahui dampak dari perilaku seksual yang mereka lakukan, seperti remaja hamil di luar nikah, aborsi, penyakit kelamin. Karena kurangnya pengetahuan remaja tentang seksualitas, sehingga menimbulkan pengalaman pahit atau dengan kata lain, dari beberapa kenyataan pahit yang sering terjadi pada remaja sebagian akibat pemahaman yang keliru mengenai seksualitas.

Ikatan Penyuluhan Keluarga Berencana (IPKB) Kota Bengkulu menyebutkan, hasil survey yang dilakukan lembaga advokasi kesehatan reproduksi remaja Provinsi Bengkulu, Centra Citra Remaja Rafflesia (CCRR) Bengkulu, didapatkan siswi tingkat SMP dan SMA di Kota Bengkulu telah melakukan hubungan seksual sebanyak 11\%, dari sample 100 siswi. Hasil melalui survei pada tahun 2008 terhadap beberapa sekolah yang ada di Kota Bengkulu, menunjukkan remaja putri usia sekolah telah melakukan hubungan seksual terhadap pacar. (CCRR Kota Bengkulu, 2009).

Berdasarkan data yang didapatkan dari Kementerian Pendidikan dan Kebudayaan, terdapat beberapa jumlah sekolah di Kota Bengkulu, jumlah siswa terbanyak ada SMKN 1 Kota Bengkulu dengan total 1.332 orang dengan jumlah siswa laki - laki 621 orang dan jumlah siswa perempuan 711 orang. Hasil survei awal yang dilakukan di SMKN 1 Kota Bengkulu tentang pergaulan yang bebas antara siswa laki -laki dan perempuan terlihat dari siswa yang sering datang dan pulang bersama pasangan masing - masing dan dapat juga dilihat sikap mereka pada 
sesama teman yang berlainan jenis. Tingginya kasus seks bebas di sebabkan oleh kemudahan memperoleh informasi tentang seks bebas. Fenomena tersebut menunjukan bahwa sebagian besar siswa belum memiliki pengetahuan dan sikap yang tepat tentang perilaku seks.

Berdasarkan uraian diatas penulis merasa tertarik untuk mengadakan penelitian guna mengkaji hubungan pengetahuan dan sikap remaja dengan perilaku seks, khususnya di SMKN 1 Kota Bengkulu.

\section{METODE}

Penelitian ini dilakukan pada bulan April 2019 di SMKN 1 Kota Bengkulu. Jenis penelitian kuantitatif dengan metode penelitian yang digunakan adalah cross sectional . Populasi dalam penelitian ini adalah seluruh siswa dan siswi kelas $\mathrm{X}$ berjumlah 480 responden. Pengambilan sampel dilakukan dengan Teknik simple random sampling. Total sampel pada penelitian ini berjumlah 80 responden. Teknik pengumpulan data yang digunakan dalam penelitian ini adalah dengan menggunakan teknik wawancara dengan menggunakan panduan kuesioner pengetahuan, sikap dan perilaku seks. Teknik analisa data menggunakan analisis univariat dan bivariat.

\section{HASIL PENELITIAN}

\section{Analisis Univariat}

Analisis univariat bertujuan untuk mengetahui gambaran pengetahuan, sikap dan perilaku seks remaja di SMKN 1 Kota Bengkulu.

Tabel 1. Gambaran distribusi frekuensi pengetahuan tentang seks pada remaja di SMKN 1 Kota Bengkulu Tahun 2019 (N=80)

\begin{tabular}{cccc}
\hline No & Pengetahuan & Frekuensi & $\begin{array}{c}\text { Persentase } \\
(\%)\end{array}$ \\
\hline 1 & Kurang Baik & 17 & $21,2 \%$ \\
2 & Baik & 63 & $78,8 \%$ \\
3 & Total & 80 & $100 \%$ \\
\hline
\end{tabular}


Berdasarkan tabel dari 80 responden (100\%), terdapat 63 responden $(78,8 \%)$ dengan pengetahuan baik dan terdapat 17 responden $(21,2 \%)$ dengan pengetahuan kurang baik.

Tabel 2. Gambaran distribusi frekuensi Sikap mengenai perilaku seks pada remaja di SMKN 1 Kota Bengkulu tahun $2019(\mathrm{~N}=80)$

\begin{tabular}{cccc}
\hline No & Sikap & Frekuensi & $\begin{array}{c}\text { Persentase } \\
(\%)\end{array}$ \\
\hline 1 & Unfavorable & 15 & $18,8 \%$ \\
2 & Favorable & 65 & $81,2 \%$ \\
4 & Total & 80 & $100 \%$ \\
\hline
\end{tabular}

Berdasarkan tabel dari 80 responden (100\%), terdapat 65 responden $(81,2 \%)$ dengan sikap favorable dan terdapat 15 responden $(18,8 \%)$ dengan sikap unfavorable.

Tabel 3. Gambaran distribusi frekuensi Perilaku Seks pada remaja di SMKN 1 Kota Bengkulu tahun $2019(\mathrm{~N}=80)$

\begin{tabular}{cccc}
\hline No & Perilaku Seks & Frekuensi & $\begin{array}{c}\text { Persentase } \\
(\%)\end{array}$ \\
\hline 1 & Resiko Tinggi & 8 & $10,0 \%$ \\
2 & Resiko Rendah & 72 & $90,0 \%$ \\
4 & Total & 80 & $100 \%$ \\
\hline
\end{tabular}

Berdasarkan tabel dari 80 responden $(100 \%)$, terdapat 8 responden $(10,0 \%)$ perilaku seks resiko tinggi, dan terdapat 72 responden $(90,0 \%)$ perilaku seks resiko rendah.

\section{Analisis Bivariat}

Analisis bivariat bertujuan untuk mengetahui hubungan antara variabel independen (pengetahuan dan sikap) dan variabel dependen (perilaku seks) di SMKN1 Kota Bengkulu. Hubungan pengetahuan dengan perilaku seks remaja dapat dilihat pada tabel 4 berikut ini.

Tabel 4. Hubungan Pengetahuan dengan perilaku seks pada remaja di SMKN 1 Kota Bengkulu tahun $2019(\mathrm{~N}=80)$

\begin{tabular}{ccccccc}
\hline \multirow{2}{*}{$\begin{array}{c}\text { Pengetahu } \\
\text { an }\end{array}$} & \multicolumn{2}{c}{ Perilaku Seks } & Total & $\chi^{2}$ & $P$ & $C$ \\
\cline { 2 - 3 } & $\begin{array}{r}\text { Resiko } \\
\text { Rendah }\end{array}$ & $\begin{array}{c}\text { Resiko } \\
\text { Tinggi }\end{array}$ & & & & \\
\cline { 2 - 3 } & $\mathrm{F}$ & $\mathrm{F}$ & & & \\
\hline
\end{tabular}




\begin{tabular}{ccccccc}
\cline { 2 - 3 } Baik & 61 & 2 & 63 & 15,3 & 0,00 & 0,40 \\
$\begin{array}{c}\text { Kurang } \\
\text { Baik }\end{array}$ & 11 & 6 & 17 & 46 & 0 & 1 \\
Total & 72 & 8 & & & & \\
\hline
\end{tabular}

Berdasarkan perhitungan pada tabel 4 di atas menunjukkan bahwa Hasil uji Exact Fisher's didapat nilai $\mathrm{p}$-Value $=0,001<0,05$ berarti signifikan, maka Ho ditolak dan Ha diterima. Jadi ada hubungan pengetahuan dengan perilaku seks remaja di SMKN 1 Kota Bengkulu.

Hasil uji Contingency Coefficient didapat nilai $\mathrm{C}=0,401$ dengan $\mathrm{p}$-value $=$ $0,000<0,05$ berarti signifikan

Karena nilai ini terletak dalam interval $0,40-0,60$ maka kategori hubungan pengetahuan dan perilaku seks remaja adalah kategori sedang.

Tabel 5. Hubungan Sikap dengan perilaku seks pada remaja di SMKN 1 Kota Bengkulu tahun $2019(\mathrm{~N}=80)$

\begin{tabular}{|c|c|c|c|c|c|c|}
\hline \multirow[t]{4}{*}{ Sikap } & \multicolumn{2}{|c|}{ Perilaku seks } & \multirow[t]{3}{*}{ Total } & \multirow[t]{3}{*}{$\chi^{2}$} & \multirow[t]{3}{*}{$P$} & \multirow[t]{3}{*}{$C$} \\
\hline & Resiko & Resiko & & & & \\
\hline & Rendah & Tinggi & & & & \\
\hline & $\mathrm{F}$ & $\mathrm{F}$ & $\mathrm{F}$ & 18,462 & 0,00 & 0,4 \\
\hline $\begin{array}{c}\text { Favorab } \\
\text { le }\end{array}$ & 63 & 2 & 65 & & 0 & 33 \\
\hline $\begin{array}{c}\text { Unfavor } \\
\text { able }\end{array}$ & 9 & 6 & 15 & & & \\
\hline Total & 72 & 8 & 80 & & & \\
\hline
\end{tabular}

Berdasarkan perhitungan pada tabel 5 di atas menunjukkan bahwa Hasil uji Exact Fisher's didapat nilai p-value $=0,000<0,05$ berarti signifikan, maka Ho ditolak dan Ha diterima. Jadi Ada hubungan sikap dengan perilaku seks pada remaja di SMKN 1 Kota Bengkulu.

Hasil uji Contingency Coefficient didapat nilai $\mathrm{C}=0,433$. Karena nilai ini terletak dalam interval $0,60-0,80$ maka kategori hubungan sikap dan perilaku seks remaja adalah kategori erat.

\section{PEMBAHASAN}


Berdasarkan hasil penelitian diketahui bahwa dari 17 responden dengan pengetahuan kurang baik terdapat 11 responden beresiko rendah, terlihat dari semua responden pengetahuan kurang tidak mengetahui hubungan seksual merupakan kebutuhan dasar yang tidak dapat dipisahkan dari kehidupan seseorang termasuk remaja. Saat wawancara langsung diketahui responden acuh tak acuh dengan lawan jenisnya. Selanjutnya terdapat 6 responden pengetahuan kurang dengan resiko tinggi, hal ini terlihat dari 6 responden yang tidak mengetahui bahwa rangsangan yang dilakukan oleh pasangan pada bagian - bagian organ seksual seperti alat kelamin dapat menyebabkan seseorang sulit mengendalikan nafsu seksualnya. Didapatkan dari hasil jawaban 6 responden tidak mengetahui bahwa perempuan bisa hamil bila melakukan hubungan seks pada masa subur (14 hari setelah haid). Saat wawancara langsung menyatakan kurangnya perhatian orang tua mengenai perilaku seks remaja.

Berdasarkan hasil penelitian diketahui dari 63 responden pengetahuan baik terdapat 61 responden dengan resiko rendah, hal ini sejalan dengan teori dimana tingkat pengetahuan seseorang akan mempengaruhi perilaku seseorang. Terdapat 2 responden pengetahuan baik namun resiko tinggi, yaitu terlihat dari jawaban 2 responden tidak mengetahui adanya tekanan dari pacar dapat mempengaruhi remaja melakukan seks bebas dan jawaban responden tidak mengetahui dengan meningkatkan keimanan dan ketakwaan terhadap Tuhan Yang Maha Esa serta belajar disiplin merupakan salah satu upaya menghadapi seks bebas. Saat wawancara langsung responden menyatakan bahwa sering bermain dilingkungan yang memiliki pergaulan bebas.

Menurut Notoadmojo (2003) pendidikan kesehatan bukanlah satu-satunya factor yang mempengaruhi perilaku seseorang tetapi dipengaruhi oleh factor pendukung eksternal yang secara langsung dapat mempengaruhi perubahan perilaku seperti sarana yang dimiliki, fasilitas lain yang tersedia atau alat-alat yang dibutuhkan serta dukungan positif yang diberikan orang lain untuk terjadi perubahan perilaku serta lingkungan. Action Situation (perilaku dipengaruhi oleh situasi lingkungan), yaitu: perilaku seksual dipengaruhi oleh situasi lingkungan sekitar, hal ini dikuatkan 
dengan adanya beberapa tempat prostitusi di Kota Semarang dan di beberapa daerah yang dikunjungi serta lingkungan tempat tinggal yang bebas (kos/kontrakan) sehingga memudahkan dalam melakukan hubungan seksual. Hal ini sejalan dengan penelitian Amaliyasari (2008), yang menyatakan bahwa perilaku seksual responden dipengaruhi Faktor kondisi lingkungan sosial yang tidak sehat atau rawan, lingkungan yang bebas bagi remaja dapat mendukung untuk berperilaku tidak wajar. Hal ini didukung dengan penelitian yang dilakukan oleh Pranoto (2009), Pada penelitian tersebut dengan jumlah responden 98, menunjukkan bahwa remaja yang berpengetahuan baik sebesar 15\%, 77\% berpengetahuan sedang dan 4\% berpengetahuan kurang.

Pengetahuan seseorang berhubungan dengan perilakunya karena dengan pengetahuan yang baik akan memperlihatkan perilaku yang baik pula, sedangkan pengetahuan yang kurang atau salah mengakibatkan perilaku yang tidak benar juga. Semakin tinggi pengetahuan seseorang semakin baik pula tingkat perilakunya (Hargiyati, 2016). Penelitian ini sejalan dengan penelitian sebelumnya yang dilakukan oleh Pratama (2014), yang menunjukan hasil bahwa kelompok responden yang mempunyai pengetahuan yang baik mempunyai perilaku yang baik pula. Berdasarkan hasil penelitian diketahui bahwa dari 15 responden dengan sikap unfavorable, terdapat 9 responden resiko rendah, hal ini terlihat dari pernyataan sikap sebagian besar responden menjawab sangat tidak setuju untuk mengatakan tidak bila pacar mengajak berhubungan seks merupakan cara yang tepat dalam mengambil keputusan karena menyangkut masa depan dan harga diri. saat wawancara langsung responden banyak melakukan aktifitas kerohanian seperti sholat, mengaji dan perkumpulan siswa bagian kerohanian. Terdapat 6 responden sikap unfavorable dengan resiko tinggi, hal ini terlihat dari sebagian besar responden setuju untuk melakukan rangsangan pada alat kelamin pasangan merupakan hal yang wajar dalam berpacaran karena melakukan rangsangan bukan berarti melakukan hubungan seksual (hubungan antar kelamin).

Berdasarkan hasil penelitian dari 65 responden dengan sikap baik, terdapat 63 responden resiko rendah, hal ini sejalan dengan teori dimana sikap akan 
berpengaruh terhadap perilaku yang akan dilakukan. Selanjutnya terdapat 2 responden dengan sikap baik namun resiko tinggi yaitu dalam pernyatan sikap sangat setuju untuk melakukan hubungan seks sebelum menikah sah - sah saja karena berhubungan seks berarti serius dengan pacar dan sangat setuju melakukan seks bebas merupakan suatu hal yang trendi saat ini karena mengikuti perkembangan zaman. Saat wawancara langsung diketahui responden mengganggap berhubungan dengan lawan jenis meupakan hal yang biasa saja karena sudah dewasa. Hal ini sejalan dengan penelitian Mahmuda (2016), didapatkan nilai $\mathrm{p}=0,039$, artinya ada hubungan bermakna antara sikap terhadap berbagai perilaku seksual dengan perilaku seksual remaja di Kota Padang $(p<0,05)$. Hal ini sesuai dengan hasil penelitian Pawestri (2013) dimana terdapat hubungan yang bermakna secara signifikan antara sikap dengan perilaku seks remaja dengan nilai $p$ value 0,017\%. Digunakan uji Rank Spearman didapatkan nilai r sebesar 0,268 artinya semakin positif sikap berarti semakin baik perilaku seks pranikah. Sikap sebagai bentuk dari perilaku yang masih tertutup sangat erat kaitannya dengan perilaku sendiri. Hasil penelitian ini didukung oleh penelitian yang dilakukan oleh Dewi (2009), bahwa dari 150 responden didapatkan sebanyak $88,7 \%$ remaja bersikap positif terhadap seksual (kecenderungan menghindari perilaku seksual pranikah). Dari hasil penelitian menunjukan pengetahuan dan sikap berhubungan dengan perilaku seks pada remaja. Oleh karena itu sangat diharapkan untuk adanya informasi tambahan pendidikan kesehatan mengenai perilaku seks dan dampak dari perilaku seks itu sendiri sehingga dapat meminimalkan resiko negatif yang terjadi pada remaja yang melakukan perilaku seks bebas. Untuk pendidikan kesehatan dapat dilakukan dari pihak instansi sekolah dengan bekerja sama melalui guru bagian bimbingan konseling seperti memberikan pendidikan kesehatan, pemutaran video dampak dari seks bebas, cara - cara mencegah terjadinya perilaku seks, cara berkomunikasi dan bergaul yang baik, agar dapat meningkatkan pengetahuan dan memberikan dampak yang positif untuk masa depan para remaja.

\section{KESIMPULAN}


Terdapat hubungan yang signifikan antara pengetahuan dengan perilaku seks remaja dengan kategori sedang dan terdapat hubungan yang signifikan antara sikap dengan perilaku seks pada remaja dengan kategori erat.

\section{SARAN}

Pengetahuan siswa tentang perilaku seks dan dampaknya pada remaja perlu ditingkatkan dengan memberikan pelayanan konsultasi dan penyuluhan atau pendidikan kesehatan di lingkungan sekolah SMKN 1 Kota Bengkulu, melalui peran guru bimbingan konseling sehingga merubah sikap dan perilaku remaja agar terhindar dari perilaku seks bebas di kalangan remaja.

\section{Daftar Pustaka}

Ali, M., Ansori, M. (2006). Psikologi Remaja : perkembangan peserta didik. Jakarta : Bumi Aksara.

Amaliyasari, Y., Puspitasari, N. (2008). Perilaku Seksual Anak Usia Pra Remaja di Sekitar Lokalisasi dan Faktor yang Mempengaruhi. Jurnal Penelitian Dinas Sosial, vol. 7 no. 1, 54-60.

Andriani, Githa. (2013). Hubungan Faktor Personal Dengan Perilaku Seksual Remaja Pada Mahasiwa Program Studi DIII Kebidanan Fakultas Kesehatan Universitas Respati Yogyakarta. (Tesis). Universitas Respati Yogyakarta, Yogyakarta.

Badan Koordinasi Keluarga Berencana Nasional. (2003). Buku sumber untuk advokasi keluarga berencana, kesehatan reproduksi, gender, dan pembangunan kependudukan. Jakarta : Badan Koordinai KB Nasional.

BKKBN Bengkulu, 24 Januari (2013). Pengetahuan kesehatan reproduksi remaja Bengkulu rendah. Berita Satu. https://www.beritasatu.com/kesehatan/93340bkkbn-pengetahuan-kesehatan-reproduksi-remaja-bengkulu-rendah. Diakses pada tanggal 20 Mei 2019.

BKKBN Kemenkes. RI (2013). Survey demografi dan kesehatan Indonesia 2012. http://kesga.kemkes.go.id/images/pedoman/SDKI-2012-RemajaIndonesia.pdf. Diakses pada tanggal 21 Mei 2019.

Depkes RI. (2003). Indikator Indonesia Sehat 2010 dan Pedoman Penetapan Indikator Provinsi Sehat dan Kabupaten/Kota Sehat. Jakarta : Depkes RI. 
Dewi, I. N. C. T. (2009). Pengaruh faktor personal dan lingkungan terhadap perilaku seksual pranikah pada remaja di SMA Negeri 1 Baturraden dan SMA Negeri 1 Purwokerto (Tesis). Universitas Diponegoro, Semarang. Diakses pada tanggal 23 Mei 2019

Dianawati, A. (2006). Pendidikan Seks untuk Remaja. Jakarta: PT. Kawan.

Glasier, A., dan Gebbie, A. (2005). Keluarga Berencana dan Kesehatan Reproduksi. Jakarta : EGC.

Hargiyati, A. I., Hayati, S., dan Maidartati. (2016). Hubungan pola asuh orang tua dengan perilaku seks pranikah pada remaja usia (15-18) tahun di SMA X Kabupaten Bandung. Jurnal Ilmu Keperawatan, vol. IV no. 2, 129-140. doi: 10.31311/.v4i2.311. Diakses pada tanggal 23 Mei 2019.

Hurlock, E . (2007). Psikologi Perkembangan Suatu Pendekatan Sepanjang Tentang Kehidupan. Jakarta : Erlangga.

IPKB Ikatan Penyuluhan Keluarga Berencana Bengkulu, (2009). Survey kesehatan reproduksi remaja Provinsi Bengkulu. Bengkulu, CCRR Kota Bengkulu.

Kartono, K. (2006). Psikologi Wanita. Bandung: Mandar Maju.

Mahmuda, Yasinda. (2016). Faktor-faktor yang Berhubungan dengan Perilaku Seksual Remaja di Kota Padang. Jurnal Kesehatan Andalas, Vol. 5. No. 02, 1-8. doi : http://doi.org/10.25077/jka.v5i2.538. Diakses pada tanggal 4 Juli 2019.

Notoatmodjo. (2003). Pengantar pendidikan kesehatan dan ilmu prilaku kesehatan. Jakarta : Rhineka Cipta.

Pranoto, J. (2009). Hubungan Pengetahuan Dan Sikap Remaja Terhadap Tindakan Hubungan Seksual Pranikah Di SMK Negeri X Medan (Tesis). Universitas Sumatera Utara, Medan. Diakses pada tanggal 4 Juli 2019.

Prawirohardjo, S. (2005). Buku ajar Ilmu Kandungan. Jakarta : Yayasan Bina Pustaka.

Sarwono, S., W. (2012). Psikologi Remaja. Jakarta: PT. Raja Grafindo Persada.

Sarwono., Sarlito, W. (2006). Psikologi remaja : definisi remaja. Jakarta: Raja grafindo persada.

Soetjiningsih, (2004). Tumbuh Kembang Remaja dan Permasalahannya. Jakarta : Sagung Seto.

Sofyan, Willis. S. (2012). Remaja dan masalahnya. Bandung: Alfabeta. 